\title{
Finite Element Analysis of Heat Treated Wood Filled Styrene Maleic Anhydride (SMA) Copolymer Composites
}

\section{Analiza kompozita od kopolimera stirena i anhidrida maleinske kiseline (SMA) punjenih pregrijanim drvom metodom konačnih elemenata}

Original scientific paper $\bullet$ Izvorni znanstveni rad

Received-prispjelo: 23. 2. 2018.

Accepted-prihvaćeno: 10. 12. 2018.

UDK: $630 * 812.71 ; 630 * 812.794 ; 630 * 863$

doi: $10.5552 /$ drvind.2019.1808

\begin{abstract}
The computer aided three dimensional static analyses of the specimens was done by using the Finite Element Method (FEM) and obtained data was compared with actual test data. The aim of this study is to compare the deformation/stress analyses with FEM analysis results of styrene maleic anhydride (SMA) copolymer composites. The heat treated wood/SMA copolymer composites were produced from different loadings (from 10 to $30 \mathrm{wt}$. \%) of heat treated and untreated eastern white pine wood flours (Pinus strobus L.). All formulations of wood flour/SMA copolymer composites were produced by melt compounding through injection molding. The deformation/stress results obtained from the experimental solutions are very close to the results obtained from the numerical solutions (SAP2000 V17). As a result, it can be said that it is beneficial to use the FEM in the engineering design approach after the data obtained by the experimental solutions as meaningful values after application of the FEM.
\end{abstract}

Key words: wood polymer composite, styrene maleic anhydride (SMA), finite element method

SAŽETAK - Računalom potpomognuta trodimenzionalna statička analiza uzoraka provedena je metodom konačnih elemenata (FEM). Dobiveni su podatci uspoređeni sa stvarnim ispitnim podatcima. Cilj rada bio je usporediti analizu deformacija/naprezanja s rezultatima FEM analize kompozita od kopolimera stirena i anhidrida maleinske kiseline (SMA). Kompoziti od pregrijanog drva i SMA kopolimera bili su izrađeni s različitim udjelom (od 10 do 30 \% težine) drvnog brašna od pregrijanoga i nepregrijanog drva američkog borovca (Pinus strobus L.). Sve formulacije kompozita od drvnog brašna i SMA kopolimera bile su izrađene injekcijskim prešanjem. Re-

\footnotetext{
${ }^{1}$ Author is lecturer at University of Bulent Ecevit, Caycuma Vocational School, Furniture and Decoration Programme, Zonguldak, Turkey, ${ }^{2}$ Author is lecturer at İzmir Demokrasi University, Engineering Faculty, İzmir, Turkey. ${ }^{3}$ Author is lecturer at School of Forest Resources, Advanced Structures and Composite Center, Maine, USA.

${ }^{1}$ Autor je predavač Sveučilišta Bulent Ecevit, Strukovna škola Caycuma, Program za namještaj i dekoracije, Zonguldak, Turska. ${ }^{2}$ Autor je predavač Sveučilišta İzmir Demokrasi, Tehnički fakultet, İzmir, Turska. ${ }^{3}$ Autor je predavač Škole za šumske resurse, Centar za napredne strukture i kompozite, Maine, SAD.
} 
zultati deformacija i naprezanja dobiveni eksperimentalno vrlo su slični rezultatima dobivenim računskim putem (SAP200 V17). Može se zaključiti da je analiza metodom konačnih elementa, kombinirana s eksperimentalno dobivenim podatcima, korisna u inženjerskom projektiranju.

Ključne riječi: drvno-plastični kompoziti, SMA, metoda konačnih elemenata

\section{INTRODUCTION} 1. UVOD

In the recent years, more interest has been reported on wood composites as engineering materials because of renewable, biodegradable resources, no waste problems, and superior mechanical properties (Mackerle, 2005). Wood plastic composite (WPC) has gained the interest of material engineers because of its structural properties (El-Haggar and Kamel, 2011). Some of its main properties are high durability, low maintenance, strength and stiffness, lower prices and decrease in bio-degradation, which makes the composites suitable for outdoor applications. Some of the applications of these composites are: decking, sheathing, roof tiles, window trim and automobile parts. WPCs perform like conventional wood; however, they are not stiff and may require special fasteners or design changes. WPCs are still stiffer than plastics (Clemons and Caufield, 2005).

A developing class of materials, including WPC has favorable attributes - they are cost effective and have good performance (Bledzki et al., 2002; Aydemir et al., 2014a; Aydemir et al., 2014b; Aydemir et al., 2015a; Aydemir et al., 2015b; Zor et al., 2016; Bardak et al., 2016; Sözen et al., 2017). The industrial manufacturing arena has paid superior attention to the use of wood as reinforcing filler for thermoplastics (Kishi et al., 1988; Maidas et al., 1988; Woodhams et al., 1984; Yam et al., 1990). The injection molding process and thermoforming of interior parts is used along with styrene maleic anhydride (SMA) copolymer in the automotive industry (ARCO Chemical Company, 1990). The main reason for the choice of maleic anhydride is to enhance the properties of the copolymer. The importance of using SMA lies in the fact that it demonstrates a similar behavior to maleic anhydride polypropylene (MAPP) (Takase and Shiraishi, 1989).

In the last four decades, the finite element method (FEM), used in numerous areas of structural analysis, has been used in the engineering application process, as well. Structural analysis should determine the effects of the loads on physical structures and their components. These physical structures and their components, subjected to this type of analysis, have to withstand loads, pressures, torques and moments in accordance with parameters that act on them (Figure 1).

Use of fiber composite material in load bearing applications usually requires a careful study and design of the component or product to be made. This can be achieved using numerical modeling software, such as finite element analysis (FEA) software (Lim et al., 2003). However, the accuracy of the input parameters, such as mechanical and physical properties of the material, loading and constraint conditions, plays an important role in the correct prediction of the structural behavior of the composite obtained by numerical analysis. The finite element method (FEM) is a numerical technique used in the analysis of the behavior of materials or systems (Gustafsson 1995, 1996). The FEM is used for structural analysis and modeling of materials that are subject to static or dynamic loads. Similarly, furniture components and systems are designed with the aid of structural design procedures (Eckelman, 1966).

In spite of the academic and industrial interest in heat treated wood, only few studies of heat treated lignocellulosic filled polymer composites have been pub-

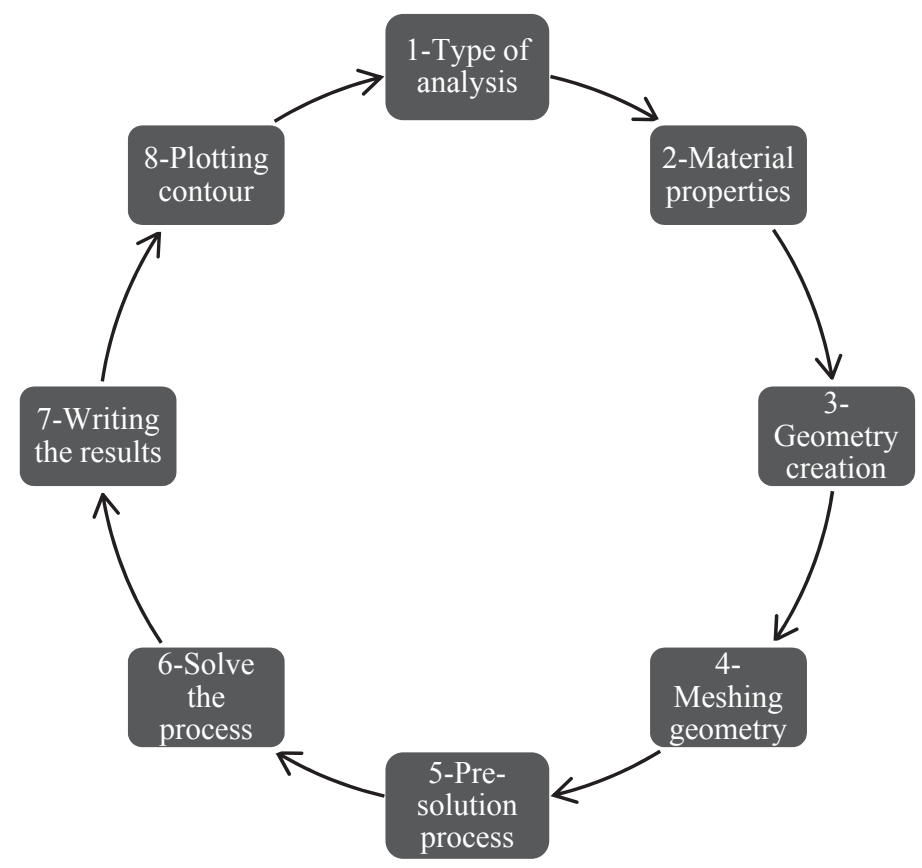

Figure 1 Process of FEM

Slika 1. Postupak analize metodom konačnih elemenata 
lished in the literature (Ayrilmış et al., 2011; Aydemir et al., 2015c; Zor et al., 2018). To the best of authors' knowledge, there is no information related to simulation analysis of heat treated lignocellulosic-filled SMA thermoplastic composites. The aim of the study is to compare the deformation analysis with the help of the open and close numerical modeling solution with the FEM.

\section{EXPERIMENTAL APPROACH}

\section{EKSPERIMENTALNI PRISTUP}

\subsection{Materials}

\subsection{Materijali}

The SMA (XIRAN® SE700) was supplied by Poyscope Polymer, USA. It has a density of $1.08 \mathrm{~g} / \mathrm{cm}^{3}$ (Maleic anhydride contents $10 \%$ wt., melt flow 22 $\mathrm{g} / 10 \mathrm{~min}$ at $240{ }^{\circ} \mathrm{C} / 10.0 \mathrm{~kg}$ ). The eastern white pine (Pinus strobus L.), used as filler in this study, was kindly supplied by Wicks Lumber in Pittsfield, ME, USA.

\subsection{Heat treatment}

\subsection{Pregrijavanje}

Pine wood samples were cut from sapwood of a radial board of eastern white pine (Pinus strobus L.). Cubic samples with dimensions of $360 \mathrm{~mm}$ x $20 \mathrm{~mm}$ x $20 \mathrm{~mm}$ were cut with clear faces, kept in a conditioned room at $20^{\circ} \mathrm{C}$ and $50 \%$ relative humidity for 3 weeks and weighed afterwards. The heat treatment was made in an oven heated by electric coils located in the walls and with exhaustion of the heated gases by natural convection through an opening in the oven wall. The treatment was applied at a temperature of $212{ }^{\circ} \mathrm{C}$ for $8 \mathrm{~h}$ (Aydemir et al. 2015b). The treatment started by putting the samples at ambient temperature in the oven. The time to reach the treatment temperature was about $60 \mathrm{~min}$. After heat treatment, the solid wood board samples were removed from the oven and ground in a grinder. Wood flour of pine greater than 60 mesh was used as raw material to prepare the wood flour/SMA copolymer composites. Untreated samples were used as the control.

\subsection{Processing of composite materials}

2.3. Proizvodnja kompozita

The wood flour retained on 60-mesh size sieve was dried to a moisture content of less than $1 \%$ using a conventional oven at $105^{\circ} \mathrm{C}$ for $16 \mathrm{~h}$. This mixture was compounded in a twin-screw extruder (C. W. Brabender
Table 1 Composition of SMA, untreated and heat treated composites

Tablica 1. Sastav kompozita od SMA, nepregrijanoga i pregrijanog drva

\begin{tabular}{|c|c|c|c|}
\hline $\begin{array}{c}\text { SMA, } \\
\%\end{array}$ & $\begin{array}{c}\text { Untreated } \\
\text { wood, \% } \\
\text { Nepregrijano } \\
\text { drvo, \% }\end{array}$ & $\begin{array}{c}\text { Heat treated } \\
\text { wood, \% } \\
\text { Pregrijano } \\
\text { drvo, \% }\end{array}$ & $\begin{array}{c}\text { Specimen } \\
\text { mark } \\
\text { Oznaka } \\
\text { uzorka }\end{array}$ \\
\hline 100 & - & - & Control \\
\hline 90 & 10 & - & $10 \mathrm{UT}$ \\
\hline 80 & 20 & - & $20 \mathrm{UT}$ \\
\hline 70 & 30 & - & $30 \mathrm{UT}$ \\
\hline 90 & - & 10 & $10 \mathrm{~T}$ \\
\hline 80 & - & 20 & $20 \mathrm{~T}$ \\
\hline 70 & - & 30 & $30 \mathrm{~T}$ \\
\hline
\end{tabular}

$20 \mathrm{~m}$ Clamshell Segmented). The temperature profile used during the extrusion was 210/220/220/220/220/210 ${ }^{\circ} \mathrm{C}$ in the respective feeding/ mixing/matrix zones with rotation of $60 \mathrm{rpm}$. The SMA-wood flour compounds were granulated using a lab-scale grinder. The ground particles were dried in an oven at $105^{\circ} \mathrm{C}$ for $16 \mathrm{~h}$ before being injection molded into ASTM test specimens. All materials were injection molded using a barrel temperature of $230{ }^{\circ} \mathrm{C}$, mold temperature of $220{ }^{\circ} \mathrm{C}$ and injection pressure of $17 \mathrm{MPa}$. The composition of the composites is shown in Table 1.

\section{NUMERICAL SOLUTION \\ 3. RAČUNSKI PRISTUP}

\subsection{Material properties}

3.1. Svojstva materijala

Finite element analysis of wood flour filled SMA composite elements was carried out using the SAP2000 V17 program. Analyses were performed by creating numerical design models based on experimental data. It was compared to the normal stresses obtained from the numerical model and the normal stresses obtained from the experiment by using the maximum load, elastic modulus and density data with 3 -point bending test. The value of vertical deformation at any point of the bar is obtained by the finite element method. Since the contribution of deformation to numerical solutions is very little, the weight of the material has been neglected. Some mechanical values entered into the program for numerical analysis of the model are given in Table 2 .

Table 2 Mechanical properties of materials entered into the program

Tablica 2. Mehanička svojstva materijala unesena u program

\begin{tabular}{|c|c|c|c|c|c|c|c|}
\hline \multirow{2}{*}{$\begin{array}{l}\text { Material properties } \\
\text { Mehanička svojstva }\end{array}$} & \multirow{2}{*}{$\begin{array}{c}\text { Control } \\
\text { Kontrola }\end{array}$} & \multicolumn{3}{|c|}{$\mathrm{UT}^{*}$} & \multicolumn{3}{|c|}{$\mathrm{T}^{* *}$} \\
\hline & & $\% 10$ & $\% 20$ & $\% 30$ & $\% 10$ & $\% 20$ & $\% 30$ \\
\hline Density / gustoća, $\mathrm{g} / \mathrm{cm}^{3}$ & 1.05 & 1.07 & 1.10 & 1.11 & 1.08 & 1.09 & 1.12 \\
\hline Elasticity modulus of bending / modul elastičnosti, GPa & 1.96 & 2.52 & 2.69 & 3.50 & 2.66 & 2.99 & 3.81 \\
\hline Poisson ratio / Poissonov omjer & \multicolumn{7}{|c|}{0.3} \\
\hline \multicolumn{8}{|l|}{ Bending stress / čvrstoća na savijanje } \\
\hline Max fracture load / najveća sila loma, $\mathrm{N}$ & 128 & 120 & 119 & 121 & 119 & 120 & 121 \\
\hline Sample properties / dimenzije uzorka & \multicolumn{7}{|c|}{$\begin{array}{l}127 \mathrm{~mm} \times 22 \mathrm{~mm} \times 3.2 \mathrm{~mm} \\
(\text { height } \times \text { weight } \times \text { thickness })\end{array}$} \\
\hline
\end{tabular}

* UT - untreated wood / nepregrijano drvo; **T - heat treated wood / pregrijano drvo 


\subsection{Finite element method (open solution)}

3.2. Metoda konačnih elemenata (otvoreni pristup)

The Finite Elements Method (FEM) is a numerical method used in engineering to analyze the behavior of materials or systems against external factors (force, heat, electricity, etc.). FEM contains the numerical solution of the mathematical model established by equalizing stiffness matrix $[K]$, deformation vector $\{u\}$ and force vector $\{F\}$ in structural static calculations. The force vector, $\{F\}$, was determined as (Eq. 1):

$$
\{\mathrm{F}\}=[\mathrm{K}]\{\mathrm{U}\}
$$

Where $\{F\}$ is the force vector, $[K]$ is the stiffness matrix, $\{u\}$ is the deformation vector.

When the force is applied to the material, the extensions of the material are proportional to stretching within the elastic limits. This is called the "Hooke Law". The modulus of elasticity is a characteristic feature of the material. The modulus of elasticity, $E$, was determined as (Eq. 2):

$$
E=\frac{\sigma}{\varepsilon}
$$

Where $E$ is the modulus of elasticity, $\sigma$ is the stress, $\varepsilon$ is the deformation.

In a beam subjected to bending, the normal stress is as given in Eq. 3.

$$
\sigma_{(\mathrm{z})}=\frac{M}{I_{\mathrm{x}}} y_{(\mathrm{z})}
$$

Where $\sigma_{(\mathrm{z})}$ is the normal stress along section height, $M$ is the bending moment at any distance of the bar, $y_{(\mathrm{z})}$ is the distance of cross-section, $I_{\mathrm{x}}$ is the moment of inertia.

If the same beam is subjected to a force (tension or compression) only in the $z$-axis direction (first local axis of the bar), a constant $\sigma_{0}$ strain occurs along the rod and section height as given in Eq. 4.

$$
\sigma_{(\mathrm{z})}=\sigma_{0}=\frac{P}{A}
$$

Where $\sigma_{0}$ is the stress, $A$ is the cross-sectional area.

\subsection{Finite element modeling (close solution) 3.3. Modeliranje konačnih elemenata (zatvoreni pristup)}

The maximum force obtained by the 3 point bending test was compared with the normal stresses obtained from the normal tensile test obtained from the numerical model using the elastic modulus and density data. In addition, the value of vertical deformation at any point of the bar is obtained by the finite element method. In this study, vertical deformations were given at the midpoint of the bar where the force was applied. Vertical deformation (Eq. 5) at any $z$ distance of a beam subjected to 3 point bending test is shown in Figure 2. 3D view of finite element model is given in Figure 3.

$$
\delta y=\frac{P \cdot L^{3}}{48 \cdot E \cdot I}
$$

Where $\delta y$ is the vertical deformation, $P$ is the applied maximum force $(\mathrm{N})$.

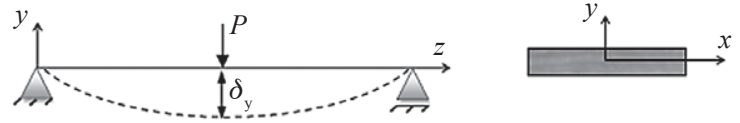

Figure 2 Example of beam subjected to 3 point bending test Slika 2. Primjer savijanja grede u tri točke

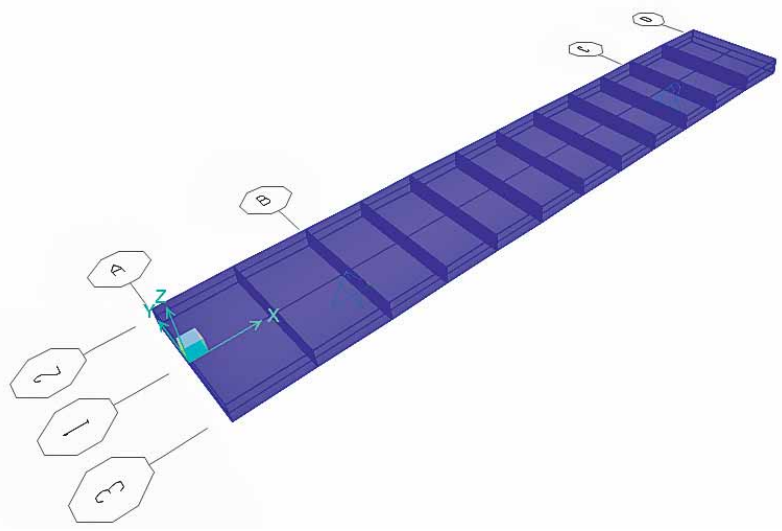

Figure 3 3D view of finite element model of the design example

Slika 3. 3D prikaz modela konačnih elemenata na projektiranom primjeru

The steps that are followed in the program to solve the problem with the FEM are given below. 1 . Creating the Model 2. Identification of Material Properties 3. Implementation of border conditions 4. Meshing 5. Analysis and evaluation of results.

\subsection{Deformation analysis with finite element modeling}

3.4. Analiza deformacije metodom konačnih elemenata

The comparison of the experimental deformation results with the data obtained with the aid of Eq. 5 is given in Table 3. Liner elastic behavior obtained by neglecting the weight of the material was analyzed numerically using the SAP2000 V17 program.

According to the 3 point bending load, the deformation results obtained with Eq. 5 and SAP2000 V17 numerical deformation results are very close to each other.

Table 4 shows the results of the maximum stresses obtained from numerical modeling with the maxi-

Table 3 Comparison of open and numerical solutions with 3-point bending load

Tablica 3. Usporedba otvorenog pristupa i zatvorenoga računskog pristupa sa savijanjem u tri točke

\begin{tabular}{|c|c|c|c|}
\hline $\begin{array}{c}\text { Materials } \\
\text { Materijali }\end{array}$ & $\begin{array}{c}\text { Open } \\
\text { solution, } \\
\mathbf{m m} \\
\text { Otvoreni } \\
\text { pristup, } \mathrm{mm}\end{array}$ & $\begin{array}{c}\text { Numerical (close) } \\
\text { solution, mm } \\
\text { Računski } \\
\text { (zatvoreni) } \\
\text { pristup, mm }\end{array}$ & $\begin{array}{c}\text { Difference, } \\
\mathbf{\%} \\
\text { Razlika, \% }\end{array}$ \\
\hline Control & 11.59 & 11.66 & 0.60 \\
\hline 10UT & 8.45 & 8.49 & 0.47 \\
\hline 10T & 7.87 & 7.91 & 0.50 \\
\hline 20UT & 7.85 & 7.98 & 1.62 \\
\hline 20T & 7.30 & 7.34 & 0.54 \\
\hline 30UT & 6.08 & 6.11 & 0.49 \\
\hline 30T & 5.45 & 5.47 & 0.36 \\
\hline
\end{tabular}


Table 4 Comparison of numerical solution and experimentally obtained stresses with 3-point bending load Tablica 4. Usporedba računskog pristupa i eksperimentalno dobivenih naprezanja sa savijanjem u tri točke

\begin{tabular}{|c|c|c|c|c|c|}
\hline $\begin{array}{c}\text { Materials } \\
\text { Materijali }\end{array}$ & $\begin{array}{c}\text { Experimental } \\
\text { solution, MPa } \\
\text { Eksperimentalni } \\
\text { pristup, MPa }\end{array}$ & $\begin{array}{c}\text { Numerical (close) } \\
\text { solution, MPa (Eq. 4) } \\
\text { Računski (zatvoreni) } \\
\text { pristup, MPa (Eq. 4) }\end{array}$ & $\begin{array}{c}\text { Difference, } \\
\text { \% } \\
\text { Razlika, \% }\end{array}$ & $\begin{array}{c}\text { Open solution, MPa } \\
\text { Otvoreni pristup, MPa } \\
\text { Difference, \% } \\
\text { Razlika, \% }\end{array}$ \\
\hline Control & 70.21 & 68.18 & 2.89 & 68.18 \\
\hline 10UT & 69.25 & 63.89 & 7.74 & 63.92 & 63.38 \\
\hline 10T & 68.9 & 62.86 & 8.76 & 63.38 \\
\hline 20UT & 63.89 & 60.39 & 7.57 & 63.92 & 9.8 \\
\hline 20T & 70.89 & 65.52 & 10.6 & 64.45 \\
\hline 30UT & 71.5 & 63.92 & 10.68 & 9.83 \\
\hline
\end{tabular}

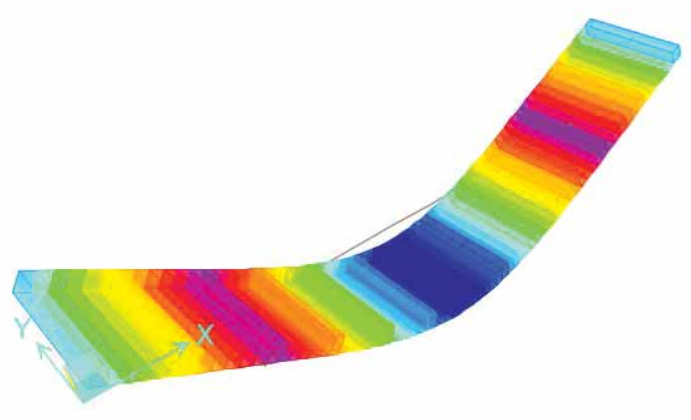

Figure 4 Total deformation diagram of the bar Slika 4. Dijagram ukupne deformacije

mum stress obtained after the experimental analysis of the samples subjected to bending strength.

In order to determine the accuracy of the experimental data in the 3-point bending load, with data obtained by the numerical model technique that used the SAP2000 V17 software, it was seen that close results were found. These results show that the sample distribution varies in the $30 \%$ composite groups. This is because, as the wood flour ratio increases during the production of the injection molding machine, the material cannot be obtained homogeneously at the desired temperature under high temperature, and the material does not exhibit the behavior of the linear isotropic material.
The maximum stress and deformation of the 3-point bending result of the pure SMA samples, which are the control samples, are shown as examples in Figures 4 and 5 .

\section{RESULTS AND DISCUSSION 4. REZULTATI I RASPRAVA}

When exposed to 3-point bending, the close solutions of the control group are received as $2 \mathrm{D}$ stress value of $68.18 \mathrm{MPa}$ and the deformation value of $-11.66 \mathrm{~mm}$. According to the experimental and open solution approaches, the deformation value difference is $0.6 \%$ and the stress value difference is $2.89 \%$.

When exposed to 3-point bending, the close solutions of $10 \%$ UT group composite are received as 2D stress value of $63.89 \mathrm{MPa}$ and the deformation value of $-8.49 \mathrm{~mm}$. According to the experimental and open solution approaches, the deformation value difference is $0.47 \%$ and the stress value difference is $7.74 \%$. When exposed to 3-point bending, the close solutions of $10 \%$ $\mathrm{T}$ group composite are received as $2 \mathrm{D}$ stress value of 62.86 $\mathrm{MPa}$ and the deformation value of $-7.91 \mathrm{~mm}$. According to the experimental and open solution approaches, the deformation value difference is $0.50 \%$ and the stress value difference is $8.76 \%$.

When exposed to 3-point bending, the close solutions of $20 \%$ UT group composite are received as 2D stress value of $60.39 \mathrm{MPa}$ and the deformation value of
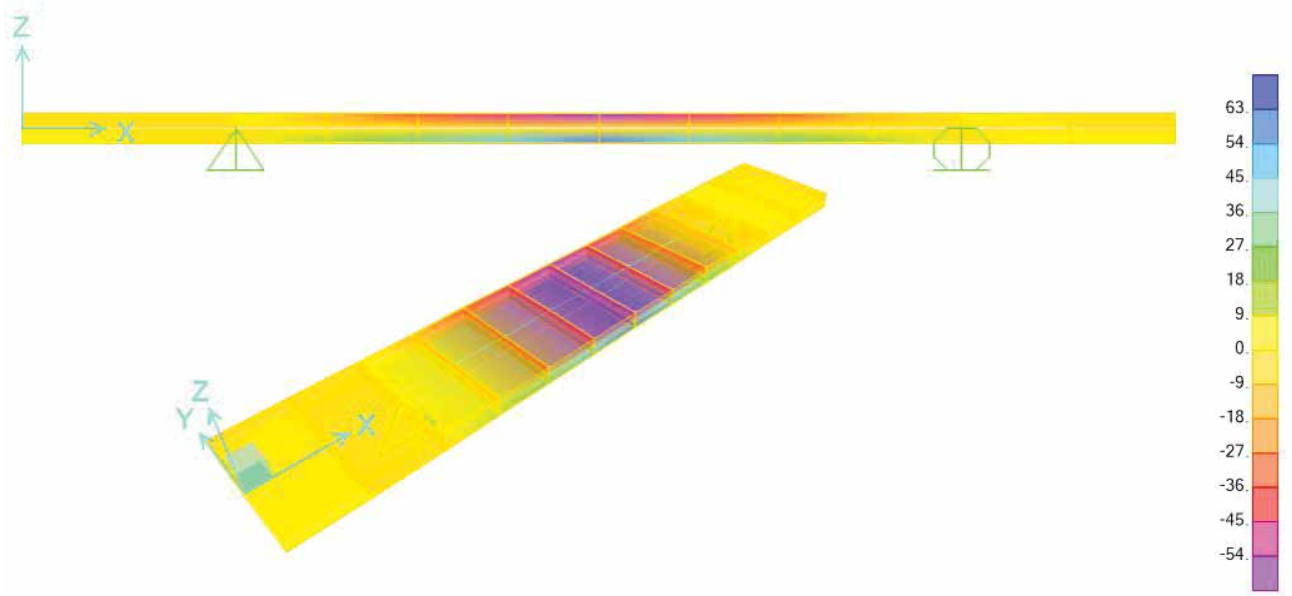

Figure 5 3D and 2D view of maximum principle stress contour diagrams (MPa)

Slika 5. 3D i 2D prikaz najvećih kontura naprezanja (MPa) 
$-7.98 \mathrm{~mm}$. According to the experimental and open solution approaches, the deformation value difference is $1.62 \%$ and the stress value difference is $5.47 \%$. When exposed to 3-point bending, the close solutions of $20 \%$ $\mathrm{T}$ group composite are received as $2 \mathrm{D}$ stress value of 65.52 $\mathrm{MPa}$ and the deformation value of $-7.34 \mathrm{~mm}$. According to the experimental and open solution approaches, the deformation value difference is $0.54 \%$ and the stress value difference is $7.57 \%$.

When exposed to 3-point bending, the close solutions of $30 \%$ UT group composite are received as 2D stress value of $63.92 \mathrm{MPa}$ and the deformation value of $-6.11 \mathrm{~mm}$. According to the experimental and open solution approaches, the difference value of deformation is $0.49 \%$ and the stress value difference is $10.60 \%$. When exposed to 3-point bending, the close solutions of $30 \% \mathrm{~T}$ group composite are received as $2 \mathrm{D}$ stress value of $63.39 \mathrm{MPa}$ and the deformation value of -5.47 $\mathrm{mm}$. According to the experimental and open solution approaches, the deformation value difference is $0.36 \%$ and the stress value difference is $10.68 \%$.

\section{CONCLUSIONS \\ 5. ZAKLJUČAK}

This study investigated the design possibilities for engineering materials by linear elastic analysis using SAP2000 V17 software. The deformations obtained by simulation were compared with experimental data. As a result of the numerical solutions carried out by finite element analyses, normal stresses were obtained along the bending beam.

When the normal stress values obtained from numerical solutions using SAP2000 V17 software are compared with the open solution using Eq. 3, it is seen that the results are very close to each other. When these values were compared with the experimental results, it was observed that the differences in the values obtained for the composites containing $30 \%$ wood flour were increased. For this reason, it can be said that the material starts to lose its homogeneous, isotropic and linear behavior. When the numerical analysis and the deformation values obtained by using Eq. 5 are compared, it is seen that the results are very close to each other.

Based on the findings obtained from the present study, it was concluded that SAP2000 V17 simulation software could be used in the calculation of the component displacements, strains, and stresses for composite/ engineering materials under internal and external loads. This reduces the need for a large number of prototypes; it requires fewer product development cycles and means lower costs (time/cost), as well as the improvement of the quality of engineering applications.

Due to the use of computer technology in the design and analysis of wood or wood based composite elements, it is possible to provide important information to product designers who can obtain preliminary information about the impacts of the loads to which a product will be exposed at the usage site before the production of a specific material.

\section{Acknowledgements - Zahvala}

The authors thank Chris West for the sample preparations. We gratefully acknowledge the Scientific and Technological Research Council of Turkey (TUBITAK-BIDEB, 2015) for the scholarship of the researcher Mustafa ZOR to do this study at the University of Maine, USA.

\section{REFERENCES}

\section{LITERATURA}

1. Aydemir, D.; Kiziltas, A.; Gardner, D. J.; Han, Y.; Gunduz, G., 2014a: Morphological characterization of foamed natural filler-reinforced styrene maleic anhydride (SMA) composites. J Porous Mater, 21: 1059-1067. http://dx.doi.org/10.1007/s10934-014-9856-x.

2. Aydemir, D.; Kiziltas, A.; Gardner, D. J.; Han, Y.; Gunduz, G., 2014b: Influence of Micro- and Nanonatural Fillers on Mechanical and Physical Properties of Foamed SMA Composites. Polymer-Plastics Technology and Engineering, 53: 1825-1831. http://dx.doi.org/10.1080/03602559.2014.935406.

3. Aydemir, D.; Kiziltas, A.; Gardner, D. J.; Han, Y.; Gunduz, G., 2015a: Thermal Analysis of Micro- and Nano Lignocellulosic Reinforced Styrene Maleic Anhydride Composite Foams. International Journal of Polymer Anal. and Charact., 20: 231-239. http://dx.doi.org/10.1080/1023666X.2015.1012792.

4. Aydemir, D.; Kiziltas, A.; Gunduz, G.; Han, Y.; Gardner, D. J., 2015b: Natural fillers-filled Styrene Maleic Anhydride Copolymer Composites. Wood Research, 60 (1): 167-174.

5. Aydemir, D.; Kızıltas, A.; Kız1ltas, E.E.; Gardner, D. J.; Gunduz, G., 2015c: Heat treated wood-nylon 6 composites. Composites: Part B, 68: 414-423.

6. Ayrılmış, N.; Jarusombuti, S.; Fueangvivat, V.; Bauchongkol, P., 2011: Effect of thermal-treatment of wood fibres on properties of flat-pressed wood plastic composites. Polymer Degradation and Stability, 96: 818-822.

7. Bardak, T.; Tankut, A. N.; Tankut, N.; Sözen, E., Aydemir, D., 2016: The Effect of $\mathrm{Nano}_{-} \mathrm{TiO}_{2}$ and $\mathrm{SiO}_{2}$ on Bonding Strength and Structural Properties of Poly (vinyl acetate) Composites. Measurement, 2016(93): 80-85. http://dx.doi.org/10.1016/j.measurement.2016.07.004.

8. Bledzki, A. K.; Sperber, V. E.; Faruk, O., 2002: Rapra Review Reports, Vol.13, No. 8.

9. Clemons, C. M.; Caulfield, D. F., 2005: Natural fibers. Functional fillers for plastics. Weinheim: Wiley-VCH, pp. 195-220.

10. Eckelman, C. A, 1966: A look at strength design of furniture. Forest Products Journal, 3 (16): 21-24.

11. El-Haggar, S. M.; Kamel, M. A., 2011: Wood Plastic Composites, Advances in Composite, 6.

12. Gustafsson, S. I., 1995: Furniture design by use of the finite element method. Holz als Roh- und Werkstoff, 53: 257-260.

13. Gustafsson, S. I., 1996: Finite element modelling versus reality for birch chairs. Holz als Roh- und Werkstoff, 54: 355-359. http://dx.10.1016/j.measurement.2016.07.004.

14. Kishi, H.; Yoshioka, M.; Yamanoi, A.; Shiraishi, N., 1988: Composites of wood and polypropylenes I. Mokuzai Gakkaishi, 43 (2): 133-139.

15. Lim, C. T.; Shim, V. P. W.; Ng, Y. H., 2003: Finite-element modeling of the ballistic impact of fabric armor. International Journal of Impact Engineering, 28: 13-31. 
16. Mackerle, J., 2005: Finite element analyses in wood research: a bibliography. Wood Science and Technology, 39 (7): 579-600.

17. Maidas, D.; Kokta, B. V.; Raj, R. G.; Sean, S. T., 1988: Use of wood fibers as reinforcing fillers for polystyrene. Materials Sci. and Engineering, A104: 235-244. http://dx.doi.org/10.1016/0025-5416(88)90425-9.

18. Sözen, E.; Aydemir, D.; Zor, M.; 2017: The Effects of Lignocellulosic Fillers on Mechanical, Morphological and Thermal Properties of Wood Polymer Composites, Drvna industrija, 68 (3) 195-204. http://dx.10.5552/drind.2017.1709.

19. Takase, S.; Shiraishi, N., 1989: Studies on composites from wood and polypropylenes, II. Journal of Applied Polymer Science, 37: 645-659. http://dx.doi.org/10.1002/ app.1989. 070370305.

20. Woodhams, R. T.; Thomas, G.; Rodgers, D. D., 1984: Wood fibers as reinforcing fillers for polyolefins. Polymer Engineering and Science, 24 (15): 1116-1171. http://dx.doi.org/10.1002/pen.760241504.

21. Yam, K.; Gogoi, B.; Lai, C.; Selke, S., 1990: Composites from com pounding wood fi bers with recycled high den- sity polyethylene. Polymer Engineering and Science, 30 (11): 693-699. http://dx.doi.org/10.1002/pen.760301109. 22. Zor, M.; Tankut, N.; Kızıltaş, A.; Gardner, D. J.; Yazıcı, H., 2016: Feasibility of Using Foamed Styrene Maleic Anhydride (SMA) Co-polymer in Wood Based Composites, Drvna Industrija, 67 (4): 399-407. http://dx.10.5552/drind.2016.1624.

23. Zor, M; Kiz1ltas, A.; Wang, L.; Gardner, D. J., 2018: Heat treated wood-filled styrene maleic anhydride (SMA) copolymer composites. Kastamonu Univ., Journal of Forestry Faculty, 18 (2): 203-214.

\section{Corresponding address:}

\section{Dr. MUSTAFA ZOR, Ph.D.}

Interior Design Programme

Caycuma Vocational School

University of Bulent Ecevit

67900, Caycuma/Zonguldak, TURKEY

e-mail: mustafa.zor@beun.edu.tr 